\title{
EFFECT OF E-PERFORMANCE AND GRANTING OF ADDITIONAL PERFORMANCE INCOME ON EMPLOYEES PERFORMANCE AT THE REGIONAL ENVIRONMENT SECRETARIAT OF LAMONGAN DISTRICT, INDONESIA
}

\author{
Astana Nurmala Arie \\ Master's Program of Human Resource Development, University of Airlangga, \\ Surabaya, Indonesia \\ E-mail: nurmalaastana92@gmail.com
}

\begin{abstract}
This study aims to determine how much influence E-Performance has on improving employee performance, then the effect of giving TPP (Employee Income Supplement) on improving employee performance, as well as the effect of E-Performance and providing Employee Income (TPP) on employee performance improvement at the Regional Secretariat Lamongan Regency. This research according to the level of exploration uses a correlational type of quantitative research method, using the exposed facto method. The purpose of the research is to be able to assist researchers in producing objective research, and can be accounted for based on the data obtained. In accordance with the nature of correlational research, researchers try to describe data and facts in accordance with the actual situation. Furthermore, the data and facts are processed and analyzed to see the effect of independent variables with the dependent variable using correlation analysis. The results obtained will be used to describe the characteristics of the population based on the variables specified. From the results of testing the hypothesis that has been done, $\mathrm{HO}$ is rejected and $\mathrm{Ha}$ is accepted. This shows that E-Performance and Additional Employee Income (TPP) have a significant effect on employee performance in the Lamongan Regency Regional Secretariat. The contribution of E-Performance and Additional Employee Income (TPP) influence on employee performance in the Regional Secretariat of Lamongan Regency can be seen from the coefficient of determination (R2). Based on the results of calculations, the $R 2$ value is $56.3 \%$. That is, E-Performance and Additional Employee Income (TPP) only have an effect of $56.3 \%$ on employee performance in the Regional Secretariat of Lamongan Regency, while the remaining $43.7 \%$ is influenced by other factors not explained in this study.
\end{abstract}

\section{KEY WORDS}

E-performance, additional employee income, employee performance, regional secretariat, Lamongan regency.

In Government Regulation No. 58 of 2005 concerning Regional Financial Management in article 63 paragraph (2) which states that "Regional Governments can provide additional income to regional Civil Servants based on objective considerations by taking into account regional financial capabilities and obtaining DPRD approval in accordance with regulatory provisions legislation". In the explanation article, it is stated that additional income is given based on work performance, place of duty, working conditions and the scarcity of the profession.

With the existence of Government Regulations and the Minister of Home Affairs Regulations, the Lamongan Regency Regional Secretariat issues Regulations on Lamongan Regent Number 04 of 2017 concerning the provision of Additional Income to Employees. Additional income is provided in the context of improving employee welfare based on workload, place of duty, working conditions, professional scarcity, work performance and or other objective considerations. Additional workload based income is given to employees who are burdened with jobs to complete tasks that are considered to be beyond normal workloads. Additional income based on working conditions is given to employees who in carrying out their duties are in a high risk work environment. The purpose of providing additional income is to motivate employees to work actively and creatively so that they can 
increase work productivity with measurable quality and quantity. Providing additional income for employees in the Lamongan city government is intended to provide employee welfare to work optimally.

At present the level of internet usage as a means of searching information and communication media is very high. Similarly, in the development of the current government system, the government is expected to maximize the use of information technology, especially the internet, to support performance and improve the quality of services to the public.

Based on the phenomena that occur, the Lamongan Regency Government carries out the recording of the performance of Civil Servants (PNS) working on all government agencies in Lamongan Regency which is a periodic assessment of the implementation of the work of a Civil Servant (PNS) in the Regional Device Organization (OPD). The purpose of recording this performance is to find out the success or failure of a Civil Servant (PNS), and to find out the weaknesses and strengths possessed by the Civil Servants (PNS) concerned in carrying out their duties and functions. The results of recording performance are used as material for consideration in fostering Civil Servants (PNS), including appointments, promotions, appointments, education and training, and the provision of additional income support.

The performance evaluation of Civil Servants (PNS) is carried out based on Government Regulation Number 10 of 1979 concerning Evaluation of the Implementation of Civil Servants' Work. The elements assessed in carrying out the assessment of the implementation of work are loyalty, work performance, responsibility, obedience, honesty, cooperation, initiative and leadership. The implementation of employee work is the process of activities carried out to evaluate the level of implementation of work or performance (Performance Appraisal) of an employee. In the Civil Servants (PNS) environment it is known as SKP (Employee Performance Target) which is regulated in Government Regulation Number 46 of 2011 . The way to assess quality aspects in a job / activity is to refer to the parameters in BKN Head Regulation Number 01 of 2013 on page 20, so based on the description above, the Lamongan District Government through the Lamongan District Civil Service Agency in order to follow and utilize the progress of information technology that is developing so as to make an E-Performance application to facilitate the Civil Servants (PNS) of the Lamongan Regency Government to do daily journal entries that are done daily.

Table 1 - Employee's performance data of regional secretariat of Lamongan district (Quarter IV 2017 and quarter I in 2018)

\begin{tabular}{|c|c|c|c|c|c|c|c|c|c|}
\hline \multirow[t]{2}{*}{ NO } & \multirow[t]{2}{*}{ BAGIAN } & \multicolumn{2}{|c|}{$\begin{array}{c}\text { KETEPATAN } \\
\text { WAKTU } \\
\text { PEKERJAAN (\%) }\end{array}$} & \multicolumn{2}{|c|}{$\begin{array}{l}\text { KESESUAIAN } \\
\text { TARGET (\%) }\end{array}$} & \multicolumn{2}{|c|}{$\begin{array}{c}\text { ORIENTASI } \\
\text { PELAYANAN (\%) }\end{array}$} & \multicolumn{2}{|c|}{ KEPEMIMPINAN (\%) } \\
\hline & & 2017 & 2018 & 2017 & 2018 & 2017 & 2018 & 2017 & 2018 \\
\hline 1 & PEMERINTAHAN & 72 & 75 & 73 & 75 & 73 & 76 & 78 & 81 \\
\hline 2 & ADM. PEMERINTAHAN DESA & 75 & 77 & 74 & 79 & 73 & 76 & 77 & 80 \\
\hline 3 & KESMAS & 75 & 77 & 72 & 76 & 74 & 74 & 76 & 79 \\
\hline 4 & HUKUM & 71 & 69 & 72 & 73 & 73 & 75 & 74 & 78 \\
\hline 5 & PEREKONOMIAN & 76 & 74 & 70 & 69 & 70 & 67 & 76 & 77 \\
\hline 6 & ADM. PEMBANGUNAN & 72 & 76 & 76 & 80 & 73 & 77 & 79 & 82 \\
\hline 7 & UNIT LAYANAN PENGADAAN & - & 70 & - & 71 & - & 74 & 0 & 75 \\
\hline 8 & BUMD & 74 & 74 & 72 & 73 & 73 & 76 & 77 & 81 \\
\hline 9 & BINA ASET & 73 & 74 & 75 & 80 & 76 & 80 & 80 & 82 \\
\hline 10 & ORGANISASI & 75 & 76 & 77 & 81 & 77 & 78 & 81 & 82 \\
\hline 11 & HUMAS \& PROTOKOL & 72 & 68 & 75 & 71 & 75 & 76 & 78 & 80 \\
\hline 12 & UMUM & 75 & 77 & 77 & 78 & 77 & 74 & 77 & 79 \\
\hline & RATA-RATA & 67,5 & 73,9 & 67,8 & 75,5 & 67,8 & 75,3 & 71,1 & 79,7 \\
\hline
\end{tabular}

Source: BKD Kab. Lamongan, 2017.

The Lamongan District Government has overseen the performance and determination of the amount of performance money as a form of reward for employee performance that will be given based on the results of the implementation of E-Performance since December 2017. Through the implementation of this E-performance, employees are given the authority to participate in E-Performance applications by filling in work data or daily journals. EPerformance is an employee performance management information system that is more 
objective, measurable, accountable, participatory and transparent, so employees can be formed based on work performance and employee career systems in the Lamongan Regency Government.

The initial data that the authors collected related to the performance of employees in the Lamongan Regency Regional Secretariat in the fourth quarter of 2017 and the first quarter of 2018 are as follows in Table 1.

Table 2 - Level of attendance of regional secretariat employees in Lamongan district (Quarter IV 2017 and quarter I in 2018)

\begin{tabular}{|c|c|c|c|c|c|}
\hline \multirow{2}{*}{ No } & \multirow{2}{*}{ BAGIAN } & \multicolumn{2}{|c|}{ KETEPATAN WAKTU FINGER PRINT (\%) } & \multicolumn{2}{|c|}{ TINGKAT KEHADIRAN APEL (\%) } \\
\hline & & 2017 & 2018 & 2017 & 2018 \\
\hline 1. & BAGIAN PEMERINTAHAN & 65 & 67 & 65 & 66 \\
\hline 2. & ADMINISTRASI PEMERINTAHAN DESA & 67 & 70 & 68 & 70 \\
\hline 3. & KESEJAHTERAAN MASYARAKAT & 63 & 69 & 65 & 69 \\
\hline 4. & HUKUM & 65 & 69 & 66 & 71 \\
\hline 5. & PEREKONOMIAN & 65 & 67 & 65 & 68 \\
\hline 6. & ADM. PEMBANGUNAN & 66 & 68 & 66 & 67 \\
\hline 7. & UNIT LAYANAN PENGADAAN & - & 68 & - & 69 \\
\hline 8. & BUMD & 69 & 73 & 70 & 72 \\
\hline 9. & BINA ASSET & 70 & 73 & 72 & 75 \\
\hline 10. & ORGANISASI & 66 & 69 & 66 & 67 \\
\hline 11. & HUMAS \& PROTOKOL & 63 & 65 & 62 & 65 \\
\hline 12. & UMUM & 63 & 64 & 63 & 65 \\
\hline & RATA-RATA & 60,2 & 68,5 & 60,7 & 68,7 \\
\hline
\end{tabular}

Source: Office of Communication and Information, Kab. Lamongan in 2018.

\section{LITERATURE REVIEW}

Theory has the function of explaining and guiding in research. Therefore, the researcher explained several theories relating to the Effect of E-Performance and Additional Employee Income (TPP) on Employee Performance in the Regional Secretariat of Lamongan Regency.

E-Performance is a performance management information system that is used in the framework of assessing employee work performance that is more objective, measurable, accountable, participatory and transparent so that employee development based on work performance and career systems can be realized. This E-Performance application is being piloted in December 2017 and applied directly in January 2018.

The application of E-Performance applications in all Regional Device Organizations (OPD) within the Lamongan Regency Government has several objectives including the following:

1. As a manifestation of the attention of the Lamongan Regency Government in shaping the work culture of professional and integrity bureaucracy that is integratedly built through the development of integrated performance systems;

2. As a method of evaluation of performance contracts held every beginning of the year as a form of institutional consistency and individual commitment in the management of the Regional Budget (APBD);

3. As a medium for making daily journals as a benchmark for the performance of Civil Servants (PNS);

4. As a form of routine control and evaluation as the basis for decision making for the following year; and

5. As a basis in determining the amount of granting additional Employee Income (TPP).

This E-Performance is one of the bases for providing an additional Employee Income (TPP) of $60 \%$ while the remaining $40 \%$ is assessed from the discipline of attendance. To anticipate a fictitious performance report, your immediate boss or leader will be the filter. Each performance report on E-Performance becomes valid only if it has been checked by the direct supervisor of the employee concerned. Not all can access the application to validate performance in this application. The right of access is only given to officials in high-ranking positions, administrator positions and positions of supervisors to approve the activities carried out by the posts below to each Regional Organization Organization (OPD) structure. 
The filling time is the time of the activity. While the working hours of Lamongan employees according to the Regulations of the Lamongan Regent Number 04 of 2017 concerning Providing Additional Employee Income (TPP) are at 7:00 a.m. to 3:00 p.m. during the effective day. This application has been socialized in turns to all employees in Lamongan Regency from 16 to 29 November 2017.

Additional Employee Income (TPP) of Civil Servants (PNS) are stipulated in Government Regulation Number 14 of 1980 dated March 13, 1980. The government in implementing the provision of Additional Employee Income (TPP) has a goal in order to improve quality, work performance and to achieve effective as much as possible.

Additional Employee Income (TPP) is an addition given to employees related to attendance and performance. Regional performance allowances are improvements to existing benefits and will be a specific allowance to boost performance while ensuring fairness in the provision of benefits. Providing regional performance allowances to carry out bureaucratic reform in line with the rapid development of the times and the increasingly complex problems faced by the state, there has also been the development of governance to realize good governance with efforts to increase transparency and accountability in the management of state finances, because it needs to provide the best service for the community.

Performance is the work of an employee for a certain period compared to various possibilities, performance targets, or criteria that have been determined in advance and agreed upon.

Performance according to A.A Anwar Prabu Mangkunegara (2009: 9) suggests "Performance is the result of work achieved by someone in carrying out their duties in accordance with the responsibilities carried out achieved in the union of time periods in carrying out their work duties".

According to Rivai, Basri (2005: 14) that performance is the result or level of success of a person or the whole during a certain period in carrying out tasks compared to various possibilities, such as standard work results, targets or targets or criteria that have been predetermined and agreed upon not doing his job, then an organization will experience a failure.

This is based on the idea that the government will not run well if the Human Resources (HR) Apparatus supporting the running of the government does not have the ability to show performance and professionalism in carrying out their duties and functions. So that in this case we need a continuous development and development of Human Resources (HR) Apparatus that is supported by facilities and infrastructure as well as adequate levels of employee welfare.

Performance according to A.A Anwar Prabu Mangkunegara (2009: 9) suggests "Performance is the result of work achieved by someone in carrying out their duties in accordance with the responsibilities carried out achieved in the union of time periods in carrying out their work duties".

According to Rivai, Basri (2005: 14) that performance is the result or level of success of a person or the whole during a certain period in carrying out tasks compared to various possibilities, such as standard work results, targets or targets or criteria that have been predetermined and agreed upon.

\section{METHODS OF RESEARCH}

The location of this study took place at the Lamongan Regency Regional Secretariat, $\mathrm{KH}$. Ahmad Dahlan No. 01, Lamongan and research conducted from December 2017 to December 2018.

In this study the author uses 2 (two) types of data, namely primary data and secondary data. The data sources used by researchers came from interviews, literature studies and questionnaires.

The data used in this study are quantitative data with primary data, where the main instrument is a questionnaire containing statements regarding E-Performance, Additional 
Employee Income, and Employee Performance in the Lamongan Regency Regional Secretariat.

This study uses a population and sample of employees who get Additional Employee Income (TPP) in the Regional Secretariat of Lamongan Regency. Population is a generalization area consisting of objects / subjects that have certain qualities and characteristics set by researchers to be studied and drawn conclusions. The population in this study were all employees who received additional Employee Income (TPP) in the Lamongan District Regional Secretariat, amounting to 207 people spread over 12 (Twelve) Sections.

Table 3 - Number of Local Secretariat Staff in Lamongan Regency who Received Additional Employee Income (TPP)

\begin{tabular}{|c|l|c|}
\hline NO & \multicolumn{1}{|c|}{ UNIT KERJA } & PEGAWAI \\
\hline 1 & SEKDA & 1 \\
\hline 2 & ASISTEN & 3 \\
\hline 3 & STAF AHLI & 3 \\
\hline 4 & BAGIAN ULP & 14 \\
\hline 5 & BAGIAN ADM. PEMERINTAHAN DESA & 11 \\
\hline 6 & BAGIAN PEMERINTAHAN & 17 \\
\hline 7 & BAGIAN BPKA & 11 \\
\hline 8 & BAGIAN KEMASYARAKATAN & 11 \\
\hline 9 & BAGIAN BUMD & 9 \\
\hline 10 & BAGIAN PEREKONOMIAN & 12 \\
\hline 11 & BAGIAN UMUM & \\
\hline 12 & BAGIAN HUMAS & \\
\hline 13 & BAGIAN HUKUM & \\
\hline 14 & BAGIAN ORGANISASI & 23 \\
\hline 15 & BAGIAN PEMBANGUNAN & \\
\hline & 16 \\
\hline
\end{tabular}

Source: Bagian Bina Pengelolaan Keuangan and Asset, 2018.

From the population 137 people were taken as the research sample. The number was obtained using the Taro Yamane or Slovin formula at a significant level of 5\%.

$$
\mathrm{n}=\frac{\mathrm{N}}{\mathrm{Nd}^{2}+1}
$$

Where: $n=$ Measure sample; $N=$ population size; $d=$ Significance level $(5 \%=0.05)$.

Proportional Random Sampling is used to determine the number of samples in each section, namely random sampling of population groups by taking into account the proportion of each group in the population strata so that the smallest proportion of the population.

The number of samples for each school is as shown in the following table:

Table 4 - Number of Population and Sample of Respondents

\begin{tabular}{|c|c|c|c|c|}
\hline NO & UNIT KERJA & PEGAWAI & $S=(X / Y) \cdot n$ & $\begin{array}{c}\text { Pembulatan } \\
\text { (Jumlah Sampel }\end{array}$ \\
\hline 1 & SEKDA & 1 & 0.662 & 1 \\
\hline 2 & ASISTEN & 3 & 1.986 & 2 \\
\hline 3 & STAF AHLI & 3 & 1.986 & 2 \\
\hline 4 & BAGIAN ULP & 14 & 9.266 & 9 \\
\hline 5 & BAGIAN ADM. PEMERINTAHAN DESA & 11 & 7.280 & 7 \\
\hline 6 & BAGIAN PEMERINTAHAN & 17 & 11.251 & 11 \\
\hline 7 & BAGIAN BPKA & 11 & 7.280 & 7 \\
\hline 8 & BAGIAN KEMASYARAKATAN & 11 & 7.280 & 7 \\
\hline 9 & BAGIAN BUMD & 9 & 5.957 & 6 \\
\hline 10 & BAGIAN PEREKONOMIAN & 12 & 7.942 & 8 \\
\hline 11 & BAGIAN UMUM & 57 & 37.725 & 38 \\
\hline 12 & BAGIAN HUMAS & 23 & 15.222 & 15 \\
\hline 13 & BAGIAN HUKUM & 16 & 10.589 & 11 \\
\hline 14 & BAGIAN ORGANISASI & 9 & 5.957 & 6 \\
\hline 15 & BAGIAN PEMBANGUNAN & 10 & 6.618 & 7 \\
\hline & JUMLAH & 207 & 137.0 & 137 \\
\hline
\end{tabular}

Source: The results of observations and calculations of researchers, 2018. 
After the data is collected, the next step is data processing. The data processing techniques used in this study are data editing, coding data and tabulating data. Meanwhile the data analysis in this study is a data analysis technique with inferential statistics, where inferential statistics are concerned with data modeling and making decisions based on data analysis, namely by testing hypothesis by making influence modeling (regression) using the test formula $\mathrm{F}$.

In this study, researchers used regression analysis modeling, where one method for determining causal relationships between one variable and another variable. The causal variable is called the independent variable, the independent variable, or variable $X$. Whereas the variable affected is known as the affected variable, the dependent variable, the dependent variable, or the variable $\mathrm{Y}$.

\section{RESULT OF STUDY}

The data used in this study are primary data. Primary data is obtained by distributing questionnaires to employees of the Lamongan Regency Regional Secretariat. The questionnaire is related to the variables E-Performance, TPP (Additional Employee Income) and Employee Performance. The respondents in this study included the entire population of employees of the Regional Secretariat of Lamongan Regency, 137 people.

In this study, the first data analysis was done by testing the validity of the instrument. This is intended to maintain the accuracy and accuracy of a measuring instrument in performing its measuring function. The validity test is used to determine how precise an instrument or measuring instrument is a questionnaire to be able to do its function.

A good research instrument is of course a valid instrument, so it can be used for measurement in order to collect data. The validity of the instrument illustrates that an instrument is truly able to measure the variables to be measured in the study and is able to show the degree of conformity between the concept and the measurement results. The formula used is using ProductMoment correlation statistics.

In the validity test of this instrument, researchers used a sample of 137 respondents as a trial to calculate instrument validity. The criteria for statement items used are:

1. If $r$ count $\geq r$ table, it means the item statement is declared "valid";

2. If $r$ count $\leq r$ table, it means the item statement is declared "invalid".

The formula used by researchers in the study of the Effect of e-Performance and Giving TPP (Additional Employee Income) on Employee Performance in the Lamongan Regency Regional Secretariat is to use product moment statistics with the help of SPSS statistics version 21 . Here is the table:

Table 5 - Test Results for Validity of Variable Instruments X1

\begin{tabular}{|c|c|c|c|}
\hline $\begin{array}{c}\text { Item Pernyataan } \\
\text { (No Instrumen) }\end{array}$ & $r$ hitung & $r$ table & Keterangan \\
\hline 1 & 0,344 & 0,176 & Valid \\
\hline 2 & 0,476 & 0,176 & Valid \\
\hline 3 & 0,321 & 0,176 & Valid \\
\hline 4 & 0,278 & 0,176 & Valid \\
\hline 5 & 0,347 & 0,176 & Valid \\
\hline 6 & 0,433 & 0,176 & \\
\hline
\end{tabular}

Source: Researcher, SPSS Data Output, 2019.

The output of the SPSS version 21 program data above is the result of the validity test of the score scores of each variable statement $X 1$. Each statement is considered valid if $r$ count is greater than the rtable value searched with $n=137$ at the significance level of $5 \%$ so as to produce a value of 0.176 . In this validity test it represents the indicator.

Then it can be concluded based on table 4.1 obtained values for each item statement from variable $\mathrm{X} 1$ greater than 0.176 . That is, each item statement is declared valid. In variable X1 all items are declared valid. After testing the variable X1, E-Performance. 
The researcher tests the X2 variable validity, namely TPP (Additional Employee Income) with 5 statements as the next stage. Researchers use the SPSS version 21 program to test TPP validity (Additional Employee Income). Can be seen in the table as follows:

Table 6 - Test Results for the Validity of Variable Instruments X2

\begin{tabular}{|c|c|c|c|}
\hline $\begin{array}{c}\text { Item Pernyataan } \\
\text { (No Instrumen) }\end{array}$ & $r$ hitung & $r$ table & Keterangan \\
\hline 1 & 0,762 & 0,176 & Valid \\
\hline 2 & 0,548 & 0,176 & Valid \\
\hline 3 & 0,389 & 0,176 & Valid \\
\hline 4 & 0,187 & 0,176 & Valid \\
\hline 5 & 0,325 & 0,176 & Valid \\
\hline
\end{tabular}

Source: Researcher, SPSS Data Output, 2019.

It is concluded that based on table 4.2, all values for each statement item of variable $\mathrm{X} 2$ are greater than 0.176 . That is, each item statement is declared valid. After testing the X2 variable, namely TPP (Additional Employee Income).

The researcher also tested $Y$ variable validity, namely Employee Performance Improvement with 24 statements as the next stage. Researchers used the SPSS version 21 program to test the validity of Employee Performance Improvement. Can be seen in the table as follows:

Table 7 - Test Results for the Validity of Variable Instruments $Y$

\begin{tabular}{|c|c|c|c|}
\hline $\begin{array}{c}\text { Item Pernyataan } \\
\text { (No Instrumen) }\end{array}$ & $r$ hitung & $r$ table & Keterangan \\
\hline 1 & 0,289 & 0,176 & Valid \\
\hline 2 & 0,449 & 0,176 & Valid \\
\hline 3 & $-0,021$ & 0,176 & Tidak Valid \\
\hline 4 & 0,253 & 0,176 & Valid \\
\hline 5 & 0,359 & 0,176 & Valid \\
\hline 6 & 0,383 & 0,176 & Valid \\
\hline 7 & 0,029 & 0,176 & Tidak Valid \\
\hline 8 & 0,511 & 0,176 & Valid \\
\hline 9 & 0,309 & 0,176 & Valid \\
\hline 10 & 0,197 & 0,176 & Valid \\
\hline 11 & 0,352 & 0,176 & Valid \\
\hline 12 & 0,439 & 0,176 & Valid \\
\hline 13 & 0,332 & 0,176 & Valid \\
\hline 14 & 0,410 & 0,176 & Valid \\
\hline 15 & 0,449 & 0,176 & Valid \\
\hline 16 & 0,416 & 0,176 & Valid \\
\hline 17 & 0,361 & 0,176 & Valid \\
\hline 18 & 0,289 & 0,176 & Valid \\
\hline 19 & 0,449 & 0,176 & Valid \\
\hline 20 & 0,018 & 0,176 & Tidak Valid \\
\hline 21 & 0,123 & 0,176 & Tidak Valid \\
\hline 22 & 0,289 & 0,176 & Valid \\
\hline 23 & 0,301 & 0,176 & Valid \\
\hline 24 & 0,380 & 0,176 & Valid \\
\hline 25 & 1 & 0,176 & Valid \\
\hline
\end{tabular}

Source: Researcher, SPSS Data Output, 2019.

The researcher compares the value of ritung as an item statement about Improving the Performance of Employees of the Regional Secretariat in Lamongan Regency with a rabel value. If $r$ count $\geq$ rtable then each item of variable $Y$ statement is declared valid. Based on table 4.2 shows that there are 4 Statement Items which are less than rtable so that the data is declared invalid. While the 20 Statement Items the remaining $r$ count is greater than rtable so the data is declared valid.

After testing the validity, the next step is reliability testing. Reliability is used to maintain the reliability of an instrument or measuring instrument. By conducting this reliability test, it will produce an instrument that is truly precise and accurate. 
In this study, reliability testing was carried out using Cronbach's Alpha technique measured on an alpha cronbach scale 0 to 1 . If the scale is grouped into five classes of the same range, then the size of alpha stability can be interpreted as follows:

1. Cronbach Alpha Value 0,00 d. 0,20 , means less reliable

2. Cronbach Alpha Value 0.21 to 0.40 , means it is somewhat reliable

3. Cronbach Alpha Value 0.42 dd 0.60 , means sufficient reliability

4. Cronbach Alpha Value 0.61 to 0.80 , interpretable

5. Cronbach Alpha Value 0.81 d. 1.00 means very reliable (Triton in Azwar2000: 3)

This reliability test uses the help of SPSS version 21 , here are the results of the calculation:

Table 8 - Variable Reliability Test Results X1

Reliability Statistics

\begin{tabular}{|c|c|c|}
\hline Cronbach's Alpha & Cronbach's Alpha Based on Standardized Items & N of Items \\
\hline .614 & .570 & 7 \\
\hline
\end{tabular}

Source: Researcher, SPSS Data Output, 2019.

Table 9 - Variable Reliability Test Results X2

Reliability Statistics

\begin{tabular}{|c|c|c|}
\hline Cronbach's Alpha & Cronbach's Alpha Based on Standardized Items & N of Items \\
\hline .631 & .529 & 6 \\
\hline
\end{tabular}

Source: Researcher, SPSS Data Output, 2019.

Table 10 - Variable Reliability Test Results $Y$

Reliability Statistics

\begin{tabular}{|c|c|c|}
\hline Cronbach's Alpha & Cronbach's Alpha Based on Standardized Items & N of Items \\
\hline .663 & .680 & 25 \\
\hline
\end{tabular}

Source: Researcher, SPSS Data Output, 2019.

Based on table above, the reliability value for the E-Performance variable (Variable X1) is 0.614 and the TPP variable (Additional Employee Income) (Variable X2) is 0.631 and the Employee Performance variable ( $\mathrm{Y}$ variable) is amounting to 0.663 . To find out this reliability test, we refer to Triton in the book Azwar which classifies the scale to 5 . The results of the data calculation using the SPSS Program above the $X 1$ variable is 0.614 and $X 2$ variable is 0.631 and the $Y$ variable is 0.663 entered on the Number 4 scale, namely the value Cronbach Alpha 0.61 up to 0.80 which means this research is reliable and can be used as a measurement tool for further analysis.

Analysis prerequisite test is a requirement that must be fulfilled so that the analysis of research data can be done well.

The normality test is done to see whether the population of the data is normally distributed or not (Siregar, 2014). The normality test aims to test one of the basic assumptions of multiple regression analysis, namely the independent and dependent variables must be normally or near normal distribution (Ghozali, 2011). The simple statistical test used to test the assumption of normality is to use the normality test from Kolmogorov Smirnov. The normal method of testing data distribution is done by looking at the variable significance value, if it is significantly greater than 0.05 at the alpha significance level of $5 \%$, then it shows a normal distribution.

Based on the results of the above normality test it is known that the kolmogorovSmirnov value is 0.365 greater than 0.05 in (sig> 0.05). Then it can be concluded that all variables are normally distributed.

This multiple correlation analysis is used to determine the relationship between two independent variables ( $\mathrm{X} 1$ and $\mathrm{X} 2$ ) to the dependent variable $(\mathrm{Y})$ simultaneously. This coefficient shows how much the relationship occurs between the independent variables (X1 and $\mathrm{X} 2$ ) simultaneously towards the dependent variable $(Y)$. $R$ value ranges from 0 to 1 , if 
the value is getting closer to 1 means the relationship that occurs is getting stronger, conversely if the value is getting closer to 0 then the relationship that occurs is getting weaker.

Table 11 - Table Normality Test Results

One-Sample Kolmogorov-Smirnov Test

\begin{tabular}{|c|c|c|c|c|c|}
\hline \multicolumn{2}{|c|}{$n / n$} & X1 (E-Performance) & $\begin{array}{l}\text { X2 (Tambahan } \\
\text { Penghasilan } \\
\text { Pegawai) }\end{array}$ & $\begin{array}{c}\text { Y } \\
\text { (KinerjaPegawai) }\end{array}$ & $\begin{array}{c}\text { Unstandardized } \\
\text { Residual }\end{array}$ \\
\hline \multicolumn{2}{|c|}{$\mathrm{N}$} & 137 & 137 & 137 & 137 \\
\hline \multirow{2}{*}{$\begin{array}{c}\text { Normal } \\
\text { Parameters }^{\mathrm{a}, \mathrm{b}} \\
\end{array}$} & Mean & 3,9504 & 3,9066 & 3,9724 &, 0000000 \\
\hline & Std. Deviation & ,21744 & ,25788 & ,11576 & ,07649299 \\
\hline \multirow{3}{*}{$\begin{array}{l}\text { Most Extreme } \\
\text { Differences }\end{array}$} & Absolute & ,203 & 208 & ,128 & ,079 \\
\hline & Positive & ,154 & ,208 &, 112 &, 039 \\
\hline & Negative &,- 203 &,- 135 &,- 128 &,- 079 \\
\hline \multicolumn{2}{|c|}{ Kolmogorov-Smirnov Z } & 2,381 & 2,431 & 1,502 & ,921 \\
\hline \multicolumn{2}{|c|}{ Asymp. Sig. (2-tailed) } &, 000 &, 000 & ,022 & 365 \\
\hline
\end{tabular}

a. Test distribution is Normal.

b. Calculated from data.

According to Sugiyono (2007) guidelines for providing interpretations of correlation coefficients as follows:

1. If the value of $R$ is $0.00-0.199$ means very low;

2. If the value of $R$ is $0.20-0.399$ means low;

3. If the value of $R$ is $0.40-0.599$ means medium;

4. If the value of $R$ is $0.60-0.799$ means strong;

5. If the value of $R$ is $0.80-1,000$ means very strong.

From the results of the regression analysis, look at the output model summary and are presented as follows:

Table 12 - Table Double Correlation Analysis Results

Model Summary

\begin{tabular}{|c|c|c|c|c|}
\hline Model & $\mathrm{R}$ & R Square & Adjusted R Square & Std. Error of the Estimate \\
\hline 1 & $0,751^{\mathrm{a}}$ & 0,563 & 0,557 &, 07706 \\
\hline
\end{tabular}

a. Predictors: (Constant), X2 (Tunjangan Tambahan Penghasilan), X1 (E-Performance).

Based on the table above, the $\mathrm{R}$ number is 0.751 . This shows that there is a strong relationship between E-Performannce and TPP (Additional Employee Income) on Employee Performance.

To calculate how much influence between E-Performance (variable X1) and Additional Employee Income (variable $\mathrm{X} 2$ ) on Employee Performance ( $\mathrm{Y}$ variable), then it can be done by calculating the coefficient of determination from the number of Product Moment correlations that have been calculated, by squaring the coefficient which is determined. R2 is equal to 0 , so there is not the slightest percentage of the contribution of influence given $\mathrm{E}$ Performance (variable $\mathrm{X} 1$ ) and Additional Employee Income (variable X2) to Employee Performance (Variable $Y$ ). On the other hand R2 equals 1, then the percentage contribution of influence given by E-Performance (variable X1) and Additional Employee Income (variable $\mathrm{X} 2)$ on Employee Performance ( $\mathrm{Y}$ variable) is perfect. To facilitate the calculation of coefficients, researchers are assisted by the SPSS 21 program.

From the results of the regression analysis, look at the output module summary and presented as follows in Table 13.

Based on the table above, the number R2 (R Square) is 0.563 or $(56.3 \%)$. This shows that the contribution percentage of the variables $\mathrm{X} 1$ and $\mathrm{X} 2$ (E-Performance and TPP (Additional Employee Income)) on variable $Y$ (Employee Performance) is $56.3 \%$. Or variations in the variables $\mathrm{X} 1$ and $\mathrm{X} 2$ used in the model (E-Performance and TPP) are able to explain as much as $56.3 \%$ variable variation $\mathrm{Y}$ (Employee Performance). While the 
remaining $43.7 \%$ is influenced or explained by other variables not included in this research model.

Table 13 - Table Analysis of Determination Results (Model Summary)

Model Summary

\begin{tabular}{|c|c|c|c|c|}
\hline Model & $\mathrm{R}$ & $\mathrm{R}$ Square & Adjusted R Square & Std. Error of the Estimate \\
\hline 1 &, $751^{\mathrm{a}}$ &, 563 &, 557 &, 07706 \\
\hline
\end{tabular}

a. Predictors: (Constant), X2 (Tunjangan Tambahan Penghasilan), X1 (E-Performance).

The test that must be fulfilled for regression analysis is linearity test, aiming to ensure the relationship between the independent variables (X1 and $\mathrm{X} 2$ ) and the dependent variable $(Y)$ is linear. The guideline to see this linearity is to use a scatter plot, if the data is spread from the lower left to the upper right to form a straight line it means the regression is linear.

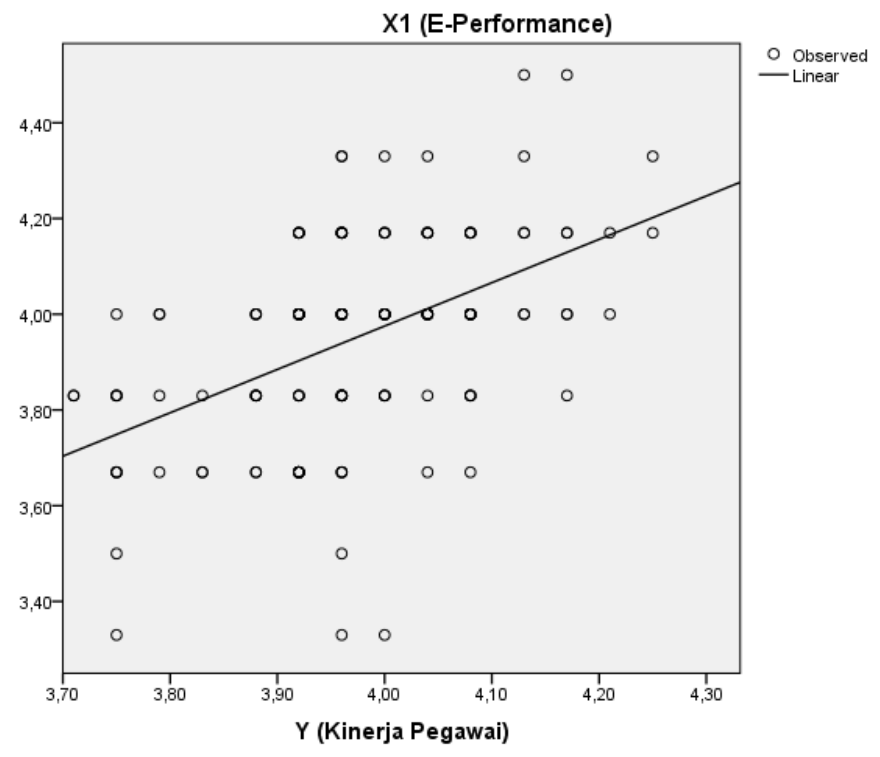

Figure 1 - Curve Scatter Plot E-Performance (Variable X1)

In the figure above shows the lines of the E-Performance curve (Variable X1) spread from the lower left to the upper right in a straight line. That means the regression is linear.

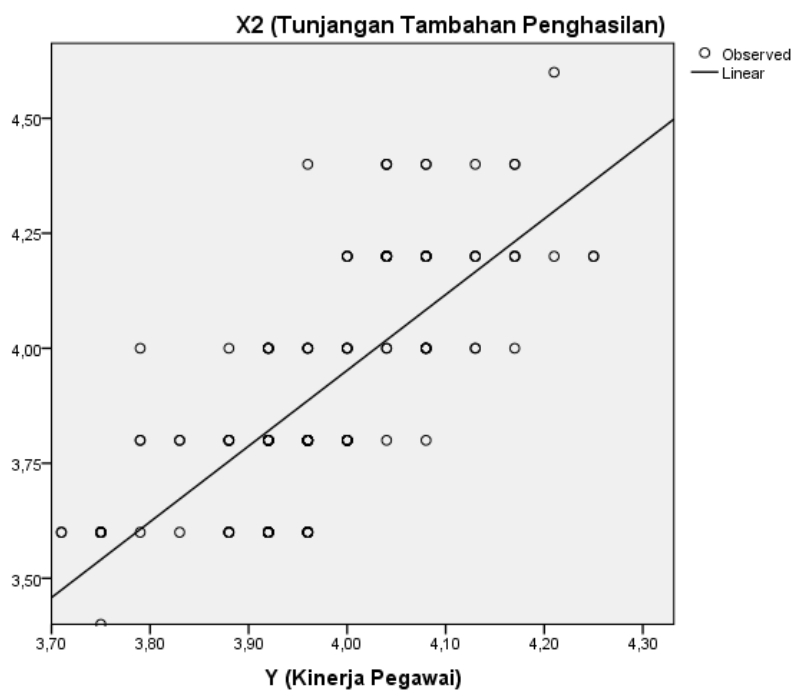

Figure 2 - Scatter Curve Employee Income Added Plot (Variable X2) 
In the figure above shows the curve of the Employee Income Supplement (Variable X2) spread from the lower left to the upper right in a straight line. That means the regression is linear.

Multiple linear regression analysis is a linear relationship between E-Performance and Additional Employee Income (variables X1 and X2) with Employee Performance (variable Y). This analysis is to determine the direction of the relationship between variables $X 1$ and $X 2$ with variable $\mathrm{Y}$ whether each variable $\mathrm{X} 1$ or $\mathrm{X} 2$ is positively or negatively related and to predict the value of variable $\mathrm{Y}$ if the value of variable $\mathrm{X} 1$ or $\mathrm{X} 2$ has increased or decreased. In this case, the researcher was assisted by the SPSS 21 program. The basic equation for multiple linear regressions:

$$
\begin{gathered}
Y=a+b 1 X 1+b 2 X 2+\ldots \\
Y(X 1)=a(X 1)+b 1(X 1) 2+b 2 X 1 X 2+\ldots \\
Y(X 2)=a(X 2)+b 1 X 1 X 2+b 2(X 2) 2+\ldots
\end{gathered}
$$

Where: $Y=$ Dependent variable (predicted value); $X 1$ and $X 2=$ Independent variables; $A=$ Constants $(Y$ value if $X 1$ and $X 2=0) ; B=$ Regression coefficient (value of increase or decrease).

\begin{tabular}{|c|c|c|c|c|c|c|c|c|}
\hline \multirow{2}{*}{\multicolumn{2}{|c|}{ Model }} & \multicolumn{2}{|c|}{$\begin{array}{l}\text { Unstandardized } \\
\text { Coefficients }\end{array}$} & \multirow{2}{*}{$\begin{array}{c}\begin{array}{c}\text { Standardized } \\
\text { Coefficients }\end{array} \\
\text { Beta }\end{array}$} & \multirow{2}{*}{$t$} & \multirow{2}{*}{ Sig. } & \multicolumn{2}{|c|}{ Collinearity Statistics } \\
\hline & & $\mathrm{B}$ & Std. Error & & & & Tolerance & VIF \\
\hline \multirow{3}{*}{1} & (Constant) & 2,492 &, 129 & & 19,342 & 000 & & \\
\hline & X1 (E-Performance) & ,080 & 035 & 150 & 2,280 & 024 & ,750 & 1,333 \\
\hline & $\begin{array}{c}\text { X2 (Tambahan } \\
\text { Penghasilan Pegawai) }\end{array}$ & 298 & ,030 & 664 & 10,074 & ,000 & 750 & 1,333 \\
\hline
\end{tabular}

Table 14 - Variable Coefficients $\mathrm{X} 1$ and $\mathrm{X} 2$ against $\mathrm{Y}$

Coefficients $^{a}$

a. Dependent Variable: Y (Kinerja Pegawai).

From the table above can be made multiple linear regression equations as follows:

$$
Y=2.429+(0.080) X 1+(0.298) X 2
$$

From the regression equation above can be explained as follows:

1. Constant of 2,429; meaning that if E-Performance (Variable X1) and additional income of employees (variable $\mathrm{X} 2$ ) the value is 0 , then the performance of employees $(\mathrm{Y})$ value is 2.429 .

2. E-Performance regression coefficient (Variable X1) of 0.080 ; meaning that if the value of $\mathrm{X} 2$ is fixed and E-Performance (Variable $\mathrm{X} 1$ ) has a $1 \%$ increase, then employee performance $(Y)$ will increase by 0.080 . The coefficient is positive, meaning that there is a positive relationship between E-Performance (Variable X1) and an increase in employee performance $(Y)$, the higher E-Performance (Variable $X 1$ ), the higher employee performance $(\mathrm{Y})$.

3. The variable regression coefficient for additional employee income (variable $\mathrm{X} 2$ ) is 0.298 ; meaning that if the value of $X 1$ is fixed and the additional income of the employee (variable $\mathrm{X} 2$ ) has a $1 \%$ increase, then the employee's performance (Y) will increase by 0.298. The coefficient is positive, meaning that there is a positive relationship between additional employee income (variable $\mathrm{X} 2$ ) and employee performance $(\mathrm{Y})$, the increase in additional employee income (variable $\mathrm{X} 2$ ), the more employee performance increases $(\mathrm{Y})$.

Hypothesis testing is done to test the proposed hypothesis. The hypothesis proposed in this study is related to disciplinary variables and work environment on employee performance. Multiple regression analysis was chosen to analyze the submission of 
hypotheses in this study. The following are the results of multiple regression analysis using the SPSS 21 program.

Simultaneous Test (F Test) aims to determine the effect of E-Performance variable (X1) and Additional Employee Income variables (X2) on Employee Performance variables $(Y)$.

Table 15 - Simultaneous Regression Coefficient Test Results (Test F)

ANOVA $^{\mathrm{a}}$

\begin{tabular}{|c|c|c|c|c|c|c|}
\hline \multicolumn{2}{|c|}{ Model } & Sum of Squares & Df & Mean Square & $\mathrm{F}$ & Sig. \\
\hline \multirow{3}{*}{1} & Regression & 1,027 & 2 &, 513 & 86,431 &, $000^{b}$ \\
\cline { 2 - 7 } & Residual &, 796 & 134 &, 006 & & \\
\hline & Total & 1,822 & 136 & & & \\
\hline \multicolumn{7}{|l|}{} \\
\cline { 2 - 7 }
\end{tabular}

a. Dependent Variable: Y (Kinerja Pegawai).

b. Predictors: (Constant), X2 (Tunjangan Tambahan Penghasilan), X1 (E-Performance).

The stages for conducting the $\mathrm{F}$ test are as follows:

1. Formulate hypotheses:

- $\mathrm{Ho}:=0$, meaning that $\mathrm{X} 1$ and $\mathrm{X} 2$ simultaneously (together) have no significant effect on $\mathrm{Y}$;

- Ho: $\neq 0$, meaning that $X 1$ and $X 2$ simultaneously (together) have a significant effect on $\mathrm{Y}$.

The rules for decision making are as follows:

- If Sig F count> Sig F table then Hoditolak;

- If Sig F count <Sig F table then Hod is accepted.

2. Determining the level of significance. The level of significance uses $a=5 \%(0.05) . A$ significance of $5 \%$ or 0.05 is a standard measure that is often used in research.

3. Determine Fcount. From the results of the SPSS calculation shown in the table above, the calculated $F$ value is 86.431 .

4. Determine Ftable. By using a 95\% significance level, $a=5 \%$, df $1=k-1=2-1=1$, df $2=n-k=137-2=135$ ( $n$ is the number of respondents and $k$ is the number of variables), the results obtained for Ftable is 3.91 .

5. Determining significance. From the calculation of SPSS, the Sig value is 0,000 . namely:

6. Criterion Testing Test $F$ (Simultaneous). In this study using two testing criteria,

$\mathrm{HO}$ is accepted if Fcount <Ftable;

$\mathrm{HO}$ is rejected if $\mathrm{F}$ count $>$ Ftable;

$\mathrm{HO}$ is accepted if the significance value is $>0.05$;

$\mathrm{HO}$ is rejected if the significance value is $<0.05$.

Based on table 4.3, the Fcount value is 86.431 with a Sig value of 0.000 . This shows that the value of Fcount is greater than Ftable3.91 and the Sig value is smaller than 0.05 . Thus $\mathrm{HO}$ is rejected and $\mathrm{Ha}$ is accepted. That is, E-Performance and TPP (Additional Employee Income) together have a significant effect on employee performance.

Partial Test (T Test) aims to determine the effect of the variable e-Performance (X1) partially (individually) on Employee Performance variables $(Y)$ and Employee Income Additional variables (X2) on Employee Performance variables $(Y)$. The hypothesis of the influence of $\mathrm{X} 1$ and $\mathrm{X} 2$ on $\mathrm{Y}$ partially (T Test) submitted in this test, as follows:

- $H o=0$, meaning that $X 1$ and $X 2$ partially (individually) have no significant effect on $Y$;

- $\mathrm{Ha} \neq 0$, meaning that $\mathrm{X} 1$ and $\mathrm{X} 2$ partially (individually) have a significant effect on $\mathrm{Y}$.

The rules for decision making are as follows:

a. If Sig thitung > Sig ttable then Hoditolak;

b. If Sig count $<$ Sig $t$ table then $\mathrm{H}$ is accepted. 
Table 16 - Partial Regression Coefficient Test Results (T Test)

Coefficients $^{a}$

\begin{tabular}{|c|c|c|c|c|c|c|c|c|}
\hline \multirow{2}{*}{\multicolumn{2}{|c|}{ Model }} & \multicolumn{2}{|c|}{$\begin{array}{l}\text { Unstandardized } \\
\text { Coefficients }\end{array}$} & \multirow{2}{*}{$\begin{array}{l}\text { Standardized } \\
\text { Coefficients } \\
\text { Beta }\end{array}$} & \multirow[t]{2}{*}{$\mathrm{t}$} & \multirow[t]{2}{*}{ Sig. } & \multicolumn{2}{|c|}{ Collinearity Statistics } \\
\hline & & B & Std. Error & & & & Tolerance & VIF \\
\hline \multirow[t]{3}{*}{1} & (Constant) & 2,492 & ,129 & & 19,342 &, 000 & & \\
\hline & X1 (E-Performance) &, 080 & ,035 & ,150 & 2,280 &, 024 & ,750 & 1,333 \\
\hline & $\begin{array}{l}\text { X2 } \\
\text { (TambahanPenghasil } \\
\text { anPegawai) }\end{array}$ & ,298 &, 030 & 664 & 10,074 &, 000 &, 750 & 1,333 \\
\hline
\end{tabular}

a. Dependent Variable: Y (KinerjaPegawai)

To find out the number of $\mathrm{T}$ tables in this study used the formula:

$$
\mathrm{Df}=\mathrm{n}-\mathrm{k}=135
$$

Where: $n=$ Number of respondents; $k=$ Number of variables $(X$ and $Y$ ).

It is known that the value of df is 135 , so that it can be seen that the $T$ table is 0.67631

in the T Distribution table with a significance of $5 \%$ or $(0.05)$.

Based on table above, it can be seen the value of tcount for each variable.

1. Effect of E-Performance (X1) on employee performance (Y). Look at the Coefficients column where there is a sig value of 0,000 , the value is smaller than the probability value of 0.05 or $0,00050.05$, then $\mathrm{H} 1$ is accepted and $\mathrm{H} 0$ is rejected. The variable $\mathrm{X} 2$ has tcount 10,074 with $t$ table 0,67631 . So tcount abel $t$ table so it can be concluded that Additional Employee Income (variable X2) has a contribution to employee performance (variable $\mathrm{Y}$ ). Positive $t$ value indicates that variable $X 1$ has a relationship that is in line with variable $Y$. So it can be concluded E-Performance has a significant influence on employee performance.

2. Effect of Additional Employee Income (X2) on employee performance (Y). Seen in the Coefficients column there is a sig value of 0.024 , the value is smaller than the probability value of 0.05 or 0.02450 .05 , then $\mathrm{H} 1$ is accepted and $\mathrm{H} 0$ is rejected. $\mathrm{X} 1$ variable has tcount 2,280 with $t$ table 0,67631 . So thitung $>t$ table so it can be concluded that E-Performance (variable $\mathrm{X} 2$ ) has a contribution to employee performance (variable $\mathrm{Y}$ ). Positive $t$ value indicates that variable $\mathrm{X} 2$ has a relationship that is in line with variable $\mathrm{Y}$. So it can be concluded that Additional Employee Income (TPP) has a significant influence on employee performance.

\section{CONCLUSION}

From the results of testing the hypothesis that has been done, $\mathrm{HO}$ is rejected and $\mathrm{Ha}$ is accepted. This shows that E-Performance and Additional Employee Income (TPP) showed a significant increase in employee performance in the Lamongan Regency Regional Secretariat. The contribution of E-Performance and Additional Employee Income (TPP) influence on employee performance in the Regional Secretariat of Lamongan Regency can be seen from the coefficient of determination (R2). Based on the results of calculations, the $\mathrm{R} 2$ value is $56.3 \%$. That is, E-Performance and Additional Employee Income (TPP) only achieved $56.3 \%$. on the performance of employees in the Lamongan Regency Regional Secretariat, while the remaining $43.7 \%$ is needed by other factors not resolved in this study.

\section{SUGGESTIONS}

Based on the results of these studies, the researchers hope that the E-Performance application will be further enhanced both to its implementation to all employees and included physical evidence of the results of employee performance to be more motivating for all employees to work. In addition, evaluation and a review of the differences in the amount of Additional Employee Income (TPP) are needed because this can also be a motivation for the work of employees. And also possible to be given sanctions if there are employees who do 
not fill in E-Performance because this will also affect the performance of government agencies in Lamongan Regency.

\section{REFERENCES}

1. Anwar Prabu Mangkunegara. 2009. Human Resource Management. Bandung: PT. Teenager Rosdakarya.

2. Azwar, S. 2000. Human Attitude, Theory and Measurement. Jogjakarta: Offset Jogja Student Library.

3. Basri, Rivai. 2005. Performance Appraisal. First print. Jakarta: PT. Raja Grafindo Persada.

4. Ilham, Muh. 2008. Resource Management and Performance of Regional Government Apparatus. Bandung: CV. Indra Pahasta.

5. Lucas, Henry J. 2000. Information Technology For Management, Irwin / Mcgraw Hill.

6. Mulyadi and Johny Setiawan, 2001, Management Planning and Control Systems, Issue 2, Jakarta: Salemba Empat.

7. Ronny Kountur. 2004. Research Methods. Jakarta: PT. Raya Grafindo Persada.

8. Sinambela, Lijan Poltak. 2012. Employee Performance. Yogyakarta: Graha Ilmu.

9. Sudarmanto. 2009. HR Performance and Competence (Theory, Dimensions of Measurement and Implementation in Organizations). Yogyakarta: Student Library.

10. Sugiyono. 2011. Business Research Methods. Bandung: Alfabeta.

11. Taniredja, Tukiran and Hidayati Mustafidah. 2012. Quantitative Research An Introduction. Bandung: Alfabeta

12. William B. Werther, Jr., Keith Davis, 1993, 4th Human Resource and Personal Management, Singapore: Mc Grow-Hill International Edition.

13. 1945 Constitution of the Republic of Indonesia.

14. Law No. 43 of 1999 concerning Amendment to Act No. 08 of 1974 concerning Staffing Principles.

15. Law No. 58 of 2005 concerning Management of Regional Finance.

16. Government Regulation Number 46 of 2011 concerning Assessing the Implementation of Civil Servants (PNS) Work.

17. Regulations of Lamongan District Head Number 04 of 2017 concerning Additional Provision of Income to employees. 